\title{
FORENSIC EXAMINATION OF A BOAR DIED DURING TRANSPORT AIMED AT REIMBURSEMENT OF INSURED ANIMAL
}

\author{
Nenad Stojanac ${ }^{1 *}$, Ognjen Stevančević ${ }^{1}$, Jasna Prodanov-Radulović ${ }^{2}$, \\ Radosav Došen ${ }^{2}$, Marko R. Cincović ${ }^{1}$, Aleksandar Potkonjak ${ }^{1}$, Vuk Vračar ${ }^{1}$ \\ ${ }^{1}$ Department of Veterinary Medicine, Faculty of Agriculture, \\ University of Novi Sad, Novi Sad, Serbia \\ ${ }^{2}$ Scientific Veterinary Institute "Novi Sad”, Novi Sad, Republic of Serbia
}

Abstract

The long lasting transport of high-value animals during the import represents the significant stress factor for animals, which can lead to severe health problems and even animal death. Thus, insurance of animals against the event of death is highly recommended. In case of the damage of the insured animal (death) it is necessary to implement all statutory and contractual measures for determining the reasons of the damage in order to effectively compensate the loss in the country, in which the animal is insured. In this article, we described the case control study, a death of breeding animal (boar) during the transport (import) from Denmark to Serbia. The animal was insured in exporting country and the forensic expertise was necessary to the purpose of adequate insurance compensation. On the basis of applied methods, which included medical history, records of clinical findings, gross pathological findings and laboratory examination, the cause of death of imported boar was identified (heart failure and suffocation). The Danish insurance company accepted the results of the examination and compensation has been successfully implemented on behalf of the dead boar.

Key words: animal insurance, transport, mortality, pigs

${ }^{1 *}$ Corresponding author: e-mail: stojanac.n@gmail.com 


\title{
FORENZIČKO ISPITIVANJE TRANSPORTNOG UGINUĆA NERASTA U SVRHU NAPLATE ŠTETE OSIGURANE ŽIVOTINJE - PRIKAZ SLUČAJA
}

\author{
Nenad Stojanac ${ }^{1}$, Ognjen Stevančević ${ }^{1}$, Jasna Prodanov-Radulović ${ }^{2}$, Radosav \\ Došen $^{2}$, Marko R. Cincović ${ }^{1}$, Aleksandar Potkonjak ${ }^{1}$, Vuk Vračar ${ }^{1}$ \\ ${ }^{1}$ Departman za veterinarsku medicine, Poljoprivredni fakulte, Novi Sad \\ ${ }^{2}$ Naučni institute za veterinarstvo "Novi Sad”, Novi Sad
}

\section{Kratak sadržaj}

Dugotrajni transport visokovrednih životinja koji se odvija prilikom uvoza predstavlja stres za životinje, koji može prouzrokovati narušavanje zdravlja pa i uginuće životinja. Upravo zbog navedenog, preporuka je da se visokovredne jedinke osiguraju u toku transporta. U slučaju nastanka štete (uginuća) kod osiguranih životinjaneophodno je sprovesti i sve propisane i ugovorene mere u cilju utvrđivanje razloga nastanka štete, kako bi se uspešno nadoknadio gubitak i u drugoj državi, u kojoj su životinje osigurane. U radu je opisan slučaj transportnog uginuća visokovrednog priplodog nerasta,prilikom uvoza iz Danske u Srbiju. Jedinka je bila osiguranau državi izvoznici i u cilju naplate osiguranja bio je neophodan argumentovan, forenzički nalaz. Na osnovu primenjenih metoda ispitivanja, koje su obuhvatale anamnestičke podatke, kliničku sliku, patomorfološki pregled i laboratorijski nalaz, utvrđen je uzrok uginuća nerasta (srčanaslabost, ugušenje). Osiguravajuće društvo države izvoznice je prihvatilo nalaz, čime je omogućena realizacija naplate štete za uginulog nerasta.

Ključne reči: osiguranje životinja, transport, uginuće, svinja

\section{INTRODUCTION}

Transport of animals represents an important stress-inducing situation that may lead to subclinical changes, clinical manifestations of poor health and even death (Malena et al., 2007; Stojanac et al., 2014). During the transport of animals, special care should be taken to ensure the welfare of animals. The transportation needs to provide appropriate conditions and satisfy physiological and other needs specific to particular animal species, such as feeding, accommodation, physical, psychological and thermal comfort and safety. Also, conditions enabling animals to demonstrate the basic behavior 
patterns, social contact with animals of the same species, absence of negative experiences (pain, suffering, fear, stress, illness and injuries) need to be provided (Official Gazette of RS, 2009). During the transport on the long distances, the stress certainly occurs (von Borell and Schaffer, 2005) and the overall ambient conditions for animals are changed. The transportation of an animals is not a narrowly defined stressor; it represents a combination of several factors since the animal is exposed to different and unknown materials, smells, light intensity, sounds and vibrations, manipulation by people, separation from the group and mixing with unfamiliar individuals, changing temperatures and air circulation, injuries, limited space, deprivation of food and water. It is suggested that, inevitably, the fact that all principles of wellbeing cannot be respected during transportation (EC, 2004).

The livestock insurance is a special branch of insurance characterized by a number of specificities, which primarily relate to the subject of insurance (animals) that function under specific biological laws. If owners or farmers want to insure their pigs (subject of insurance) against various risks, they have an obligation to pay the appropriate compensation for risk-taking. This entails additional costs and certainly increases the cost for animals insurance (Marković and Jovanović, 2010).

Insurance including coverage for risk requires fulfillment of some basic insurability criteria, including the capability to estimate the severity of risk with associated uncertainty. Conventional empirical methods are of limited use to estimate the impact of new risk data, are usually scarce and/or may not be relevant to the new disease. Hence, the feasibility of alternative methods to quantify the impact of risk should be further explored (Coble et al., 2006; Zagmutt et al., 2013). The price of risk (insurance) is a premium, which exists in all types of insurance. Farmers set aside significant funds for the livestock insurance (crop insurance) and they pay the full amount of premium (gross premium). The whole issue of livestock insurance is intended to enable faster development of livestock and to reduce damages in animal husbandry to the minimum. In the selected period, technical premium is not sufficient to cover the damages and it is necessary to try to increase it in the future. This can be achieved through better education of farmers, who could use certain preventive measures to partially mitigate the development of specific damages, and on the other hand with appropriate livestock insurance packages to try to encourage more farmers to insure their animals (Marko, 1989; Marković, 2007).

In the majority of cases, the highly valuable breeding pigs are transported on long distances (over $1000 \mathrm{~km}$ ). The long distance transportation represents substantial expenses, which increase the cost of sold goods, and therefore the- 
re is no financial justification to transport the commercial (slaughter) pigs. Depending on the final agreement, the animal insurance in the international transport may be completed by the exporter or importing country. All rights and obligations should be regulated by the contract, which clearly indicates, which contracting party bears the risk during the transport of animal. In case of any damage, the implementation of all prescribed and agreed measures for determining the cause of damage should be taken in order to compensate the loss in another country, in which the animal was ensured.

As described in this study, all animals ( 11 hogs) imported to Serbia were clinically examined by an authorized veterinarian before loading, and no clinical signs of disease or visible defects were detected. However, the exporting country, i.e., the insurance company did not agree to accept the damage on the basis of statements of the driver and the customer, and they demanded an official forensic report. In this article, the case, of death of breeding animal (boar) during the transport (import) from Denmark to Serbia was described. The animal was insured in exporting country, and with an aim of obtaining the insurance compensation, the complete forensic expertise was necessary.

\section{MATERIAL AND METHODS}

The material for this research included 11 breeding hogs, Duroc breed, imported to Serbia and settled in quarantine facility according to the official decision of the Veterinary Directorate of the Ministry of Agriculture and Environmental Protection of the Republic of Serbia. When unloading the animals, it was discovered that one of the boars died. The applied research methods included epidemiological and medical history, clinical finding records, gross pathological findings and laboratory examination of sera samples sampled from live boars as well as the tissue samples (liver, spleen, kidney, lungs, heart, mandibular, mesenteric and mediastinal lymph nodes, tonsils) derived from dead animal (bacteriological and virology testing). The serological examination for relevant bacterial (antibodies against leptospirosis, Brucella sp.) and viral diseases (antibodies against Classical Swine Fever (CSFV), Morbus Auijeszky (MA), Porcine Respiratory and Reproductive Syndrome virus (PRRSV)) was performed in line with the Quarantine Decision of the Veterinary Directorate of the Ministry of Agriculture and Environmental Protection.

Isolation of bacteria from tissue samples deriving from dead pigs was performed by standard aerobic and microaerophilic cultivation (Quinn et al., 2011).

The titer of MA specific antibodies was determined by serum neutralization test (SNT) following standard procedure as described before (O.I.E. Manual of Epizootic, 2004, section 2.1.2.). 
Determination of the presence of antibodies against the PRRSV and CSFV was performed applying ELISA (OIE, section 2.8.7) and ELISA (OIE, section 2.8.3), respectively.

\section{RESULTS AND DISCUSSION}

Pursuant to relevant medical and other documents supporting the importation license, 11 breeding boars, Duroc breed, were transported from Denmark to Serbia. All accompanying import documentation for animals was checked by the Veterinary Inspection. When unloading boars, the veterinarian discovered that one boar died. Clinical investigation revealed no signs of disorders or disease in remaining 11 boars and animals were placed in a quarantine facility. Other boars did not manifest any clinically apparent disorders. The transport of animals lasted in total 23 hours and transport routes went through several countries: Germany, the Czech Republic, Slovakia and Hungary.

The Veterinary inspector applied the official control of the certificate issued by the Danish Veterinary and Food and established the following: the health status of the boars was checked before loading, and there was no suspicion on the presence a contagious disease that can be transmitted to pigs. The certificate stated that the State of Denmark has conducted testing on all diseases requested by the Veterinary Directorate of the Ministry of Agriculture and Environmental Protection, thus confirming freedom from certain viral (MA, TGE, PRRSV, African swine fever, CSFV, foot and mouth disease, swine vesicular disease) and bacterial swine diseases (atrophic rhinitis, brucellosis, leptospirosis, swine dysentery, tuberculosis, actinobacillosis, enzootic pneumonia). Finally, it was stated that breeding boars were not transported (on the way from the place of loading to the place of unloading) through an area where contagious diseases were detected. The transport vehicles have previously been appropriately cleaned and disinfected, and meet all requirements considering animals' welfare during transport.

\section{Official control of transport vehicles}

The breeding boars were shipped by the vehicle (truck) owned by the seller from Denmark. The total floor area was about $6.9 \mathrm{~m}^{2}$ and was divided into two unequal parts $\left(4.5\right.$ and $\left.2.4 \mathrm{~m}^{2}\right)$ with $1 \mathrm{~m}$ high fence. In the larger part, seven boars were placed, and four boars were put in the back part of the vehicle. Additional control of animal space revealed a small quantity of sawdust sprinkled on the rough floor was found. The transport vehicle was equipped with the water supply (separated in two parts) as well as the ventilation system. 


\section{Clinical investigation}

While unloading the live boars from the vehicle, one carcass of dead boar was found. Clinical examination revealed no clinical signs of the disease in remaining animals. Examination of the respiratory and digestive tract as well as the locomotor and reproductive system revealed no signs of diseases in 11 breeding boars. The animals were settled in quarantine stables.

\section{Gross pathological finding}

The pathomorfological examination of dead breeding boar was performed according to standard gross pathology veterinary farm protocol. By external examination, the Duroc breed and good body condition was established. The animal body weight was estimated to some $100 \mathrm{~kg}$. The skin of dead animal was cyanotic, particularly in the area of the scrotum, preputium, chest and neck. After external examination, pathological control of internal cavities was done. In the abdominal cavity, distinct meteorism of the stomach and small intestine was discovered as well as small amount of free bloody content in the abdominal cavity. Gross pathological control of the chest cavity revealed distinct emphysema of the complete lung lobes and the presence of bloody content. After detailed examination and opening of the airways, reddish color of tracheal and mucosa of major bronchi brochs (Picture 1-A) along with the presence of blood content was observed. On lung cross-section, dark red color of the lung tissue and large amount of blood were observed (Picture 1-B).Pathological examination of the heart muscle revealed markedly expanded and significantly enlarged right ventricle (about 1.5 times larger than the left one) (Picture 1-C). In the right atrium and the heart chamber, a large amount of coagulated blood, dark red in color was discovered (Picture 1-D).

Pathomorphological diagnosis was established: Emphysema pulmonum, Hyperaemia passiva acuta pulmonis, Dilatatio passiva cordis.

\section{The results of laboratory examination}

Bacteriological testing of tissue samples obtained from dead breeding boar revealed the presence of the following bacteria: Escherichia coli, Clostridium perfringens. Serological investigation did not confirm antibodies against the examined swine diseases (MA, PRRSV, CSF, Brucela spp., Leptospirosis).

Before transporting high-value animals over long distances it is necessary to precisely define all conditions of the insurance, to specify the responsibi- 
lities of each party and what is included in the insurance. This is very important when it comes to international trade because management systems of veterinary service differ from country to country. The responsibility of the veterinary service is particularly important when assessing the damage and performing forensic testing to identify the causes of damage. In this case, the boars have been insured in Denmark and it was necessary, factually and with good arguments, to identify the cause of the death of a boar in order to charge for the loss.

In this paper, the examination of the reason for death of the boar indicated that beside the changes observed on the animal itself, the means of transport as well as the conditions under which the animals were transported played an important role. During the transportation of animals, it is necessary to ensure their well-being (Official Gazette of RS, 2009). One of the most important issues concerning the welfare of animals on long lasting transport is the adequate surface area per animal. Animals in the transport vehicle should be able to lie down and to stand when they need (RSPCA, 2010; EC, 2004). To fulfill this requirement, the minimum required space for pigs should not exceed $235 \mathrm{~kg} /$ $\mathrm{m}^{2}$, or by transported pig $(100 \mathrm{~kg})$ should be provided $0.42 \mathrm{~m}^{2}$ of floor area. Available floor area (A) can be calculated from the formula A =0,0192W0.67, where "W" is animal body weight (Voslářováisar., 2010).

Several studies reported that high stocking density reduces animal welfare and is associated with greater mortality during transport and lairage (Ritter et al., 2007; Fitzgerald et al., 2009). The spatial area in the truck, in which they boars from Denmark were transported, was divided into two parts, so the space available per one animal was $0.64 \mathrm{~m}^{2}$ in the larger part and $0.60 \mathrm{~m}^{2}$ in the smaller part of the vehicle. The boars were of an average weight of about 90 $\mathrm{kg}$, which suggests that the boars had enough floor space per animal, but one should take into account that the trip took quite a long time $(23 \mathrm{~h})$ and that all boars did not originate from the same herd. A review of the Common Veterinary Entry Document (CVED) established that the truck entered Serbia 4 hours prior to unloading and that all animals were inspected by the border veterinary inspector, who reviewed the identity and performed physical examination of the boars, marked them as "satisfactory" and accepted the import and transport to the quarantine. This indicates that the death occurred in the last part of the transportation, that is, between 19th and 23rd hour spent in the truck, and before unloading.

The severity of transport stress depends on aspects of loading and unloading as well as length of the journey, stocking density, group social hierarchies, genotype, and climatic condition (Nanni Costa, 2009). Different studies have 
been aimed at investigating the effects of season, air temperature, and length of the journey on in-transit market pig losses (Averos et al., 2008; Sutherland et al., 2009). Import of boars was carried out in July, which according to many other authors (Werner et al., 2007; Vitali et al., 2014) is the month with the highest mortality rate during pig transport. Also, the distances that are crossed during import of boars are very long, which affects the increase in mortality during transport (Haley et al., 2008; Sutherland et al., 2009) and obviously resulted in the death of boars also in this study.

\section{CONCLUSION}

On the basis of the certificate issued by the Danish Veterinary and Food Administration, Common Veterinary Entry Document (CVED), medical history, clinical presentation of other boars, autopsy findings and laboratory results it is concluded that the cause of death of the boar was heart insufficiency. Death came due to long lasting transport (23h) and large number of boars in a small space, which caused further stress in the boar. The animal obviously fell down, and traces of injuries on the skin on one side of the body indicated that the animal was trampled by other animals. In the present case, it was a very common cause of death in pigs. When animals are transported in the correct way and in compliance with the procedures that are necessary to meet the requirements for compensation, cases of animal death during transport are successfully solved within the framework of international trade obligations. Danish insurance company has accepted this finding and compensation payment for dead boar was successfully implemented.

\section{LITERATURE}

1. Averos X., Knowles T.G., Brown S.N., Warriss P.D., Gosálvez L.F.: Factors affecting the mortality of pigs being transported to slaughter. The Vet Rec, 163(13), 386-390, 2008.

2. von Borell E., Schaffer D.: Legal requirements and assessment of stress and welfare during transportation and pre-slaughter handling of pigs, review article. Livest Prod Sci,97, 81-87,2005.

3. Coble K.H., Hanson T.R., Sempier S.H., Shaik S., Miller J.C.: Investigating the feasibility of livestock disease insurance: A case study in aquaculture. Pp. 252-271 in Koontz SR, Hoag DL, Thilmany DD et al. (eds). The Economics of Livestock Disease Insurance: Concepts, Issues and International Case Studies. Wallingford, UK: CABI Publishing, 2006. 
4. EC. Counsil Regulation (EC) No 1/2005 on the protection of animals during transport and related operations and amending Directives 64/432/ EEC and 93/119/EC and Regulation (EC) No 1255/97, 2004.

5. Fitzgerald R.F., Stalder K.J., Matthews J.O., Schultz Kaster C.M., Johnson A.K.: Factors associated with fatigued, injured, and dead pig frequency during transport and lairage at a commercial abattoir. J Anim Sci, 87, 11561166, 2009.

6. Haley C., Dewey C.E., Widowski T., Poljak Z., Friendship R.: Association between in-transit loss, internal trailer temperature, and distance travelled by Ontario market hogs. Can J Vet Res, 72, 385-389, 2008.

7. Malena M., Voslářová E., Kozák A., Bělobrádek P., Bedáňová I., Steinhauser L., Večerek V.:Comparison of Mortality Rates in Different Categories of Pigs and Cattle during Transport for Slaughter. Acta Vet Brno,76: S109-16, 2007.

8. Marko J.: Osiguranje useva (plodova) i naknada štete, Agroekonomika, 18(1), 98,1989.

9. Marković T.: Razvoj osiguranja stoke u Srbiji. Letopis naučnih radova, 31(1)158-166, 2007.

10. Marković T., Jovanović M.:Livestock insurance as a factor of economic stability in the agriculture. Contemporary Agriculture, 59(3-4), 287-92,2010.

11. Nanni Costa L.: Short-term stress: The case of transport and slaughter. Ital J Anim Sci, 8, 241-252, 2009.

12. OIE. Manual of Diagnostic Test and Vaccines for Terrestrial Animals. Fifth Edition, 2004.

13. Quinn J. P., Markey K.B., Leonard C. F., Fitz S.E., Fanning S., Hartigan J.P.: Veterinary microbilology and Microbial disease, Wiley Blackwell, 196-287, 2011.

14. Ritter M.J., Ellis M., Bertelsen C.R., Bowman R., Brinkmann J., DeDecker M., Keffaber K.K., Murphy C.M., Peterson B.A., Schlipf J.M., Wolter B.F.: Effects of distance moved losses of market weight pigs on arrival at the packing plant. J Anim Sci, 85, 3454-3461, 2007.

15. RSPCA, Welfare standards for pigs. The Royal Society for the Prevention of Cruelty to Animals, UK, 2010.

16. Službeni glasnik RS. Zakon o dobrobiti životinja. Sl. glasnik RS, br. 41/2009, 2009.

17. Stojanac N., Stevančević O., Cincović M. R., Stančić I., Potkonjak A., Toholj B., Vračar V.: Forensic investigation of sow deaths in the intesive breeding system. Archives of Veterinary Medicine, Vol. 7, No. 1, 29 - 37, 2014.

18. Sutherland M.A., McDonald A., McGlone J.J.:Effects of variations in the 
environment, length of journey and type of trailer on the mortality and morbidity of pigs being transported to slaughter. Vet Rec 165, 13-18, 2009.

19. Vitali A., Lana E., Amadori M., Bernabucci U., Nardone A., Lacetera N.: Analysis of factors associated with mortality of heavy slaughter pigs during transport and lairage. Journal of animal science, 92(11), 5134-5141, 2014.

20. Voslářová E., Chloupek P., Steinhauser L., Havlíček J., Večerek V.: Influence of Housing System and Number of Transported Animals on Transport-induced Mortality in Slaughter Pigs. Acta Vet Brno, 79, S79-84, 2010.

21. Werner C., Reiners K., Wicke M.: Short as well as long transport duration can affect the welfare of slaughter pigs. Animal welfare, 16(3), 385-389., 2007.

22. Zagmutt F., Sempier S., Hanson T.: Disease Spread Models to Estimate Highly Uncertain Emerging Diseases Losses for Animal Agriculture Insurance Policies: An Application to the US Farm-Raised Catfish Industry. Risk Analysis 33.10, 1924-1937, 2013.

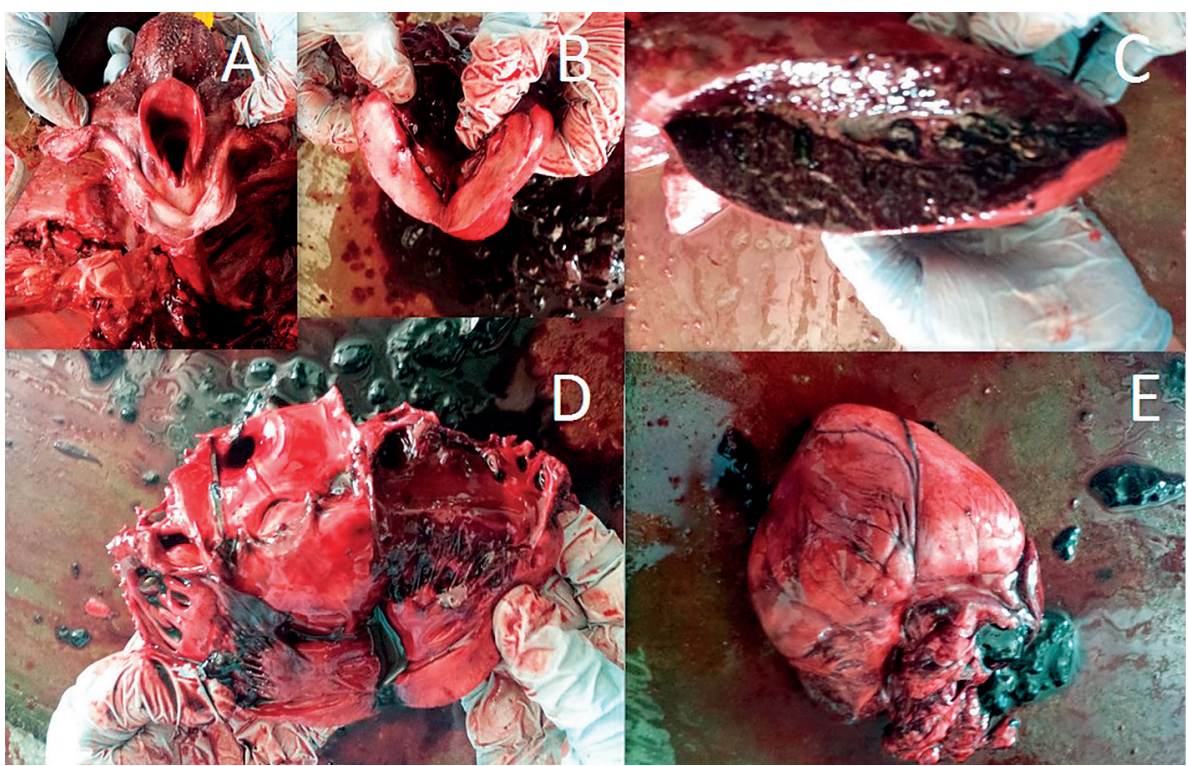

Picture1. Post-mortem examination: A, B-lung, C, D-heart. 
Arhiv veterinarske medicine, Vol. 8, No. 1, 47 - 57, 2015 Stojanac N. ... et al.: Forensic examination ...
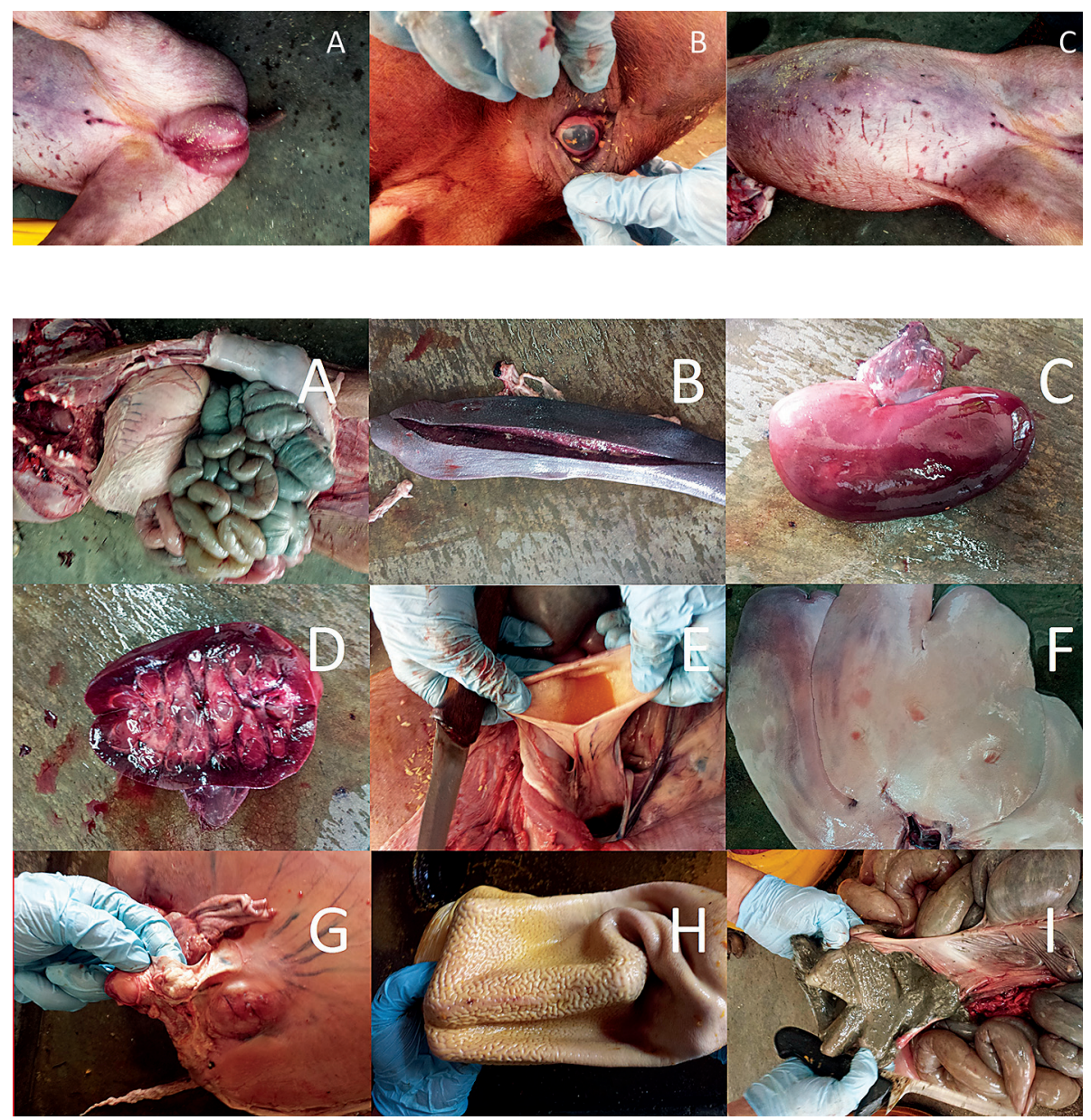